\title{
Metallothionein 2A core promoter region genetic polymorphism and its impact on the risk, tumor behavior, and recurrences of sinonasal inverted papilloma (Schneiderian papilloma)
}

\author{
Katarzyna Starska ${ }^{1}$ - Magdalena Bryśs ${ }^{2}$ Ewa Forma ${ }^{2}$. \\ Jurek Olszewski ${ }^{3}$ - Piotr Pietkiewicz ${ }^{3}$. \\ Iwona Lewy-Trenda ${ }^{4}$ • Olga Stasikowska-Kanicka ${ }^{4}$. \\ Marian Danilewicz ${ }^{4}$ Anna Krześlak ${ }^{2}$
}

Received: 17 April 2015 / Accepted: 26 May 2015 / Published online: 3 June 2015

(C) The Author(s) 2015. This article is published with open access at Springerlink.com

\begin{abstract}
Inverted papillomas are a unique group of locally aggressive benign epithelial neoplasms in the nasal cavity and paranasal sinuses arising from the Schneiderian mucosa. Metallothioneins are sulfhydryl-rich heavy metal-binding proteins required for metal toxicity protection and regulation of biological mechanisms including proliferation and invasion. The goal of this study was to identify three SNPs at loci -5 $\mathrm{A} / \mathrm{G}(\mathrm{rs} 28366003)$ and $-209 \mathrm{~A} / \mathrm{G}(\mathrm{rs} 1610216)$ in the core promoter region and at locus $+838 \mathrm{C} / \mathrm{G}$ (rs 10636) in 3'UTR region of the $M T 2 A$ gene with IP risk and with tumor invasiveness according to Krouse staging. Genotyping was performed using the PCR restriction fragment length polymorphism technique in 130 genetically unrelated IP individuals, and 418 randomly selected healthy volunteers. The presence of the rs28366003 SNP was significantly related to the risk of IP within the present population-based case-control study. Compared to homozygous common allele carriers, heterozygosity and homozygosity for the $\mathrm{G}$ variant had a significantly increased risk of IP (adjusted odds ratio [OR] $=7.71,95 \%$
\end{abstract}

Katarzyna Starska

katarzyna.starska@umed.lodz.pl

1 I Department of Otolaryngology and Laryngological Oncology, Medical University of Łódź, Kopcinskiego 22, 90-153 Łódź, Poland

2 Department of Cytobiochemistry, University of Łódź, Pomorska 142/143, 90-236 Łódź, Poland

3 II Department of Otolaryngology and Laryngological Oncology, Medical University of Łódź, Żeromskiego 113, 90-549 Łódź, Poland

4 Department of Pathology, Medical University of Łódź, Pomorska 251, 92-213 Łódź, Poland confidence interval $\left.[\mathrm{CI}]: 4.01-14.91, p_{\text {dominant }}<0.001\right)$. Moreover, risk allele carriers demonstrated higher Krouse stage (pT1 vs. pT2-4) $(\mathrm{OR}=19.32 ; 95 \% \mathrm{CI}, 2.30-173.53$; $p<0.0001)$, diffuse tumor growth $(\mathrm{OR}=4.58 ; 95 \% \mathrm{CI}$, $1.70-12.11 ; p=0.0008)$, bone destruction $(\mathrm{OR}=4.13 ; 95 \%$ CI, $1.50-11.60 ; p=0.003)$, and higher incidence of tumor recurrences $(\mathrm{OR}=5.11 ; 95 \% \mathrm{CI}, 1.68-15.20 ; p=0.001)$. The findings suggest that $M T 2 A$ gene variation rs28366003 may be implicated in the etiology of sinonasal inverted papilloma in a Polish population.

Keywords Metallothionein 2A (MT2A) · Single-nucleotide polymorphism (SNP) · Krouse staging system · Recurrences · IP · Sinonasal inverted papilloma (Schneiderian papilloma)

\section{Introduction}

Sinonasal inverted papillomas (Schneiderian papillomas) of the nasal cavity and paranasal sinuses are unique, locally aggressive, primarily benign epithelial neoplasms derived from the Schneiderian membrane with an endophytic growth pattern and proliferation in the underlying stroma. The characteristic attributes of these head and neck tumors are local invasiveness and aggressive growth with local bone destruction and a higher tendency to recur, resulting in appropriate clinical problems. Moreover, once epithelial dysplasia in IP tissues occurs, metaplasia and malignant transformation into carcinoma in situ or invasive squamous cell carcinoma may follow [1, 2]. Unfortunately, although a range of possible etiologies including possible viral (HPV infection), inflammatory, environmental, and occupational etiologies have been proposed, 
no conclusive basis has yet been identified for the development and pathogenesis of Schneiderian papillomas [3, 4].

The metallothioneins (MTs) family of low molecular mass $(6-7 \mathrm{kDa})$ proteins is a family of metal-binding and metalabsorbing, cysteine-rich molecules which affect the homeostasis of intracellular metals such as cadmium, lead, mercury, zinc, and copper [5-7]. MTs can react with heavy and trace metal ions, thus regulating intra- and extracellular distribution of the metal and its donation to various crucial transcription factors and enzymes. Hence, MTs are involved in many pathophysiological processes including metal detoxification, cell proliferation, apoptosis, and deactivation of reactive oxygen species [5-8]. The transcription of the MT gene is activated in response to a wide range of stimuli, including oxidative stressinducing agents, cytokines, hormones and various chemical agents, as well as $\mathrm{Cd}$ and $\mathrm{Zn}$ in particular $[5,6,9,10]$. A crucial role in the activation of the metal-induced MT promoter region is played by the six zinc-finger-metal-responsive transcription factor (MTF-1) and short cis-acting DNA metal response elements (MREs) as transcriptional activators and a nuclear factor I (NF-I) protein as a downregulator of MT expression [11]. MTF-1 also exerts effects on MT gene transcription by independent increase in MTF-1 DNA-binding activity $[12,13]$.

Eleven functional human MT isoforms have been identified so far. Among them, MT1/MT2 isoforms are the most active in human cells and may participate as tumor regulators in such crucial mechanisms as inhibition of NF-KB signaling, modulation of $\mathrm{p} 53$ zinc-dependent activity, as well as regulation of the PIK3/AKT and Rb/E2F pathways [9, 10, 14-17]. In the last years, several association studies have been performed which indicate that metallothioneins may be implicated in the development of various types of human neoplastic diseases and determine the clinical course of many tumors, e.g., larynx, breast, kidney, lung, ovary, prostate, testis, urinary bladder, cervical or pancreatic cancers $[5,9,10,14,17-19]$. Due to the multidirectional nature of intracellular MT activity and possible participation in such crucial tumorigenic processes as differentiation, proliferation, angiogenesis and response to oxidative stress species, many researchers examine its relationship as a potential biomarker with the etiology, progression and prognosis of various tumors, but with ambiguous and often conflicting results $[5-7,9,10,14,17,18,20]$.

Recently, an individual genetic variation identified in the core promoter region of MTs and the diverse frequency of essential MT alleles, in particular MT2A, was shown to be associated with the risk of various human tumors in some ethnic populations $[5,10,18,20-23]$. The contribution of single-nucleotide polymorphisms (SNPs) in the MT2A gene to variation in the cellular activities of metallothioneins and the signaling of MT-dependent pathways may steer the enhancement of tumor development and growth toward increased DNA damage, enhanced genomic instability, deregulated cell proliferation, inhibited apoptosis, and induced oxidative stress $[6,8]$. Thus, in the last half decade, research has been focused on the identification of the aftermath and the mechanisms through which the presence of SNPs in some genes, inter alia the MT2A gene, may induce a malignant cell phenotype and determine cell proliferation, growth and tumor invasion. However, such individual studies concern only neoplasms of the head and neck region in such locations as the nasopharynx, salivary glands, tongue, or larynx [10, 24-27]. Although the data indicates that the presence of SNPs in MT genes has an impact on MT1/MT2 expression, and that the occurrence of different genotypes are associated with cancer risk, tumor behavior, and chemotherapy resistance in head and neck cancers, these findings have not been unambiguously confirmed, and other studies suggest a range of final conclusions [10, 24-27]. Despite conflicting data, most research indicates that changes identified in the core promoter region in the $M T 2 A$ gene near the TATA box may be considered as novel biomarkers of risk and tumor invasiveness, as well as a potential new therapeutic targets for treatment strategies to modify or inhibit neoplastic development and progression of various types of tumors [5, 10, 18, 20-23].

Unfortunately, a literature survey reveals no publication describing the activity of $M T 2 A$ isoforms and their relationship with the risk and tumor clinical behavior in sinonasal Schneiderian papillomas. Moreover, the etiology of this disease is largely unknown, although epidemiological studies suggest the involvement of viral, immunologic and occupational factors. Therefore, more research is needed to better understand the possible biological mechanisms of development and the potential role of both MT2A expression and genetic polymorphism in the $M T 2 A$ gene core promoter region in this rare, locally aggressive tumorigenic process.

The present population-based case-control study was aimed at investigating the genetic association between the risk of sinonasal inverted papilloma (Schneiderian papilloma) in inhabitants of Poland, and the presence of three selected single-nucleotide polymorphisms: at loci $-5 \mathrm{~A} / \mathrm{G}$ (rs28366003) and $-209 \mathrm{~A} / \mathrm{G}$ (rs1610216) in the core promoter region and at locus $+838 \mathrm{C} / \mathrm{G}$ (rs10636) in $3^{\prime} \mathrm{UTR}$ region of the $M T 2 A$ gene. In addition, the effect of these SNPs on allelespecific gene expression and invasiveness of neoplastic process according to Krouse staging and incidence of recurrences has been identified.

\section{Materials and methods}

\section{Study population and lifestyle risk factors}

In this study, 130 tissue samples, including sinonasal inverted papilloma (Schneiderian papilloma) cases from genetically unrelated individuals ( 89 male and 41 female, mean age 
$59.14 \pm 12.66$ years), recruited between January 2003 and December 2014, were selected and investigated. The patients were under treatment at the I and II Departments of Otolaryngology and Laryngological Oncology, Medical University of Łódź, Poland. All patients had received a confirmed diagnosis of inverted papilloma (IP) based on histopathological evaluation and had undergone functional endoscopic sinonasal surgery (FESS), although this was dependent on the extent of neoplastic lesions described by CT scans of nasal cavity and paranasal sinuses performed before surgery and assessed during an earlier FESS procedure. The observation period after surgical treatment ranged from 5 to 154 months (mean period $59.37 \pm 37.63$ months). Recurrence occurred after FESS in 18 $(13.8 \%)$ cases in the group studied. Sinonasal squamous cell carcinoma (SCC) associated with IP (synchronous carcinoma) was found in one case in group studied. The IP samples were collected from the tumor localized in nasal cavities and/or paranasal sinuses. The criteria for patient participation in this study were as follows: (1) a pathologically confirmed diagnosis of sinonasal inverted papilloma (Schneiderian papilloma), (2) a negative history of previously diagnosis with other types of primary cancers, (3) a negative history of receiving prior immuno-, radio- or chemotherapy due to other types of primary neoplasms. The control group comprised 418 randomly selected healthy volunteers in the same age group (314 male and 104 female, mean age $64.17 \pm 8.28$ years) as previously described [19]: all controls were non-related individuals who had never been diagnosed with head and neck tumors nor any other neoplasms, nor had they received prior immuno-, radioor chemotherapy for other reasons. All of the studied individuals, patients and controls were Caucasians from the same ethnic and geographical origins, living in the Łódź region of central Poland. Informed consent was obtained from patients and controls.

Socio-demographic data, health-related information and cigarette smoking status were obtained from each participant. In all cases, surveys were performed to complete the tumor registry database. The database catalog was queried every 6 months and all histopathologically confirmed incidents of sinonasal inverted papilloma cases reported within 6 months of diagnosis preceding the recruitment were identified. Smoking status was categorized into "current", "former", and "never" based on self-reported usage. Individuals who reported smoking at least 100 cigarettes in their lifetime and who, at the time of survey, smoked either every day or some days were classified as a current smoker. Individuals who reported smoking at least 100 cigarettes in their lifetime and who had not been smoking for at least 3 months were defined as a former smoker. Participants who reported never having smoked 100 cigarettes were defined as a never smoker. A positive family history of head and neck region neoplasms was defined as being self-reported in at least one first-degree relative with known neoplastic disease.

\section{Histological classification and morphological features}

All tissue samples were fixed in $10 \%$ neutral buffered formalin, embedded in paraffin, and routinely processed for histological examination. Archival paraffin-embedded tissue samples were used for the histological classification of tumors. At this point in the study, all formalin-fixed, paraffin-embedded (FFPE) slides were carried out in a single reference laboratory and evaluated by two independent pathologists without prior knowledge of patient clinical data. When differences in opinion occurred between the two investigators, agreement was reached by subsequent careful discussion. The inverted papilloma tissues used in this study in each case were selected individually from several FFPE tissue sections which had been estimated pathologically. H\&E-stained sections provided a histological confirmation of IP. Sinonasal inverted papillomas were classified with the Krouse staging system [28]. The IP were typed histopathologically according to the IARC WHO classification of head and neck tumors [29]. Morphological estimation was performed on H\&E-stained sections in at least five different regions of the invasive, peripheral part of the tumor ( $\times 200$ magnification). The histological evaluation considered the histological type (exophytic and endophytic growth), the presence of dysplasia (mild or severe), bone destruction, anatomical area occupation and any association with malignancy.

\section{Immunohistochemistry}

Paraffin-embedded tissue sections were mounted onto SuperFrost slides, deparaffinized, then treated in a microwave oven in a solution of target retrieval solution (TRS, $\mathrm{pH}$ 6.0, Dako) for $30 \min (2 \times 6 \min 360 \mathrm{~W}, 2 \times 5180 \mathrm{~W}, 2 \times 4 \mathrm{~min}$ $90 \mathrm{~W})$ and transferred to distilled water. Endogenous peroxidase activity was blocked by $0.3 \%$ hydrogen peroxide in distilled water for $30 \mathrm{~min}$, and then sections were rinsed with Tris-buffered saline (TBS, Dako, Denmark) and incubated 30 min with primary mouse monoclonal antibodies against: Ki67 (Dako; clone MIB1, dilution 1:50). Immunoreactive proteins were visualized using EnVision-HRP kit (Dako, Carpinteria, CA, USA) according to the instructions of the manufacturer. Visualization was performed by incubation the sections in a solution of 3,3'-diaminobenzidine (DakoCytomation, Denmark). After washing, the sections were counter-stained with hematoxylin and coverslipped. For each antibody and for each sample, negative controls were processed. Negative controls were carried out by incubation in the absence of the primary antibody and always yielded negative results. All immunohistochemical analyses were carried out in a single reference laboratory and evaluated by light microscopy blindly and independently by two pathologists. Ki67 staining was performed routinely in all cases of dysplasia and/or in those cases in which the histological evaluation 
of H\&E-stained sections aroused any suspicion of increased proliferation of tumor cells. Ki67 was scored as the percentage of nuclei-stained cells out of all tumor cells in the front of the neoplasm regardless of the intensity in $\times 400$ high-power field, 500 to 1000 tumor cells were counted in each case. We classify IHC Ki67 expression into two categories according to the score of Ki67: low ( $<14 \%$ Ki67-positive cells) and high ( $\geq 14 \%$ Ki67-positive cells).

\section{Sample collection and DNA and extraction from FFPE}

The tissue specimens from sinonasal inverted papilloma collected in the operation room were prepared and evaluated by an experienced pathologist as mentioned above. Sections were deparaffinized by two rinses in xylene and ethanol. After deparaffinization, samples were rehydrated. The tissue was collected by centrifugation. After the final wash, alcohol was aspirated and the tissue pellets were resuspended in digestion buffer $(10 \mathrm{mM} \mathrm{NaCl}, 500 \mathrm{mM}$ Tris- $\mathrm{HCl}, \mathrm{pH}$ 8.0, $25 \mathrm{mM}$ EDTA, $1 \%$ SDS) and $1 \mathrm{mg} / \mathrm{ml}$ proteinase $\mathrm{K}$ was added. Sections were incubated at $50{ }^{\circ} \mathrm{C}$ overnight. Prior to deoxyribonucleic acid (DNA) purification, proteinase $\mathrm{K}$ was inactivated by incubation at $97^{\circ} \mathrm{C}$ for $10 \mathrm{~min}$. The digested samples were extracted using TRI Reagent (Sigma Aldrich Co., USA) according to the manufacturer's protocol. Venous blood samples were obtained from each volunteer $(10 \mathrm{ml})$ and transferred to test tubes containing EDTA as an anticoagulant. After blood collection, the tube was inverted 8-10 times and placed in a refrigerator at $-20^{\circ} \mathrm{C}$. Blood samples obtained from the participants were stored at $-20^{\circ} \mathrm{C}$ within $2 \mathrm{~h}$ of removal. DNA was isolated by standard method using proteinase $\mathrm{K}$ digestion, phenol chloroform extraction and ethanol precipitation. The investigations were performed with the approval of the Bioethical Commission of the Medical University of Łódź and the National Science Council, Poland (approval No RNN/60/13/KE).

Genotyping for the rs28366003, rs1610216, and rs10636 allelic variants was performed as described previously $[18,19]$.

\section{Statistical data analysis}

Genotype distributions were evaluated for agreement with Hardy-Weinberg equilibrium by the Chi-square test $\left(\chi^{2}\right)$. All genotype distributions of MT2A fit the Hardy-Weinberg equilibrium. Unconditional multiple logistic regression models were used to calculate odds ratios (ORs) and $95 \%$ confidence intervals (CIs) for the association of genotype with inverted papilloma risk. Genotype data was analyzed with the homozygote of the common allele as the reference group. Variants of homozygotes and heterozygotes were combined to evaluate the dominant effect. For each SNP, trend tests were conducted by assigning the values 1,2 , and 3 to homozygous wild type, heterozygous, and homozygous variant genotypes, respectively, and by adding these scores as a continuous variable in logistic regression model.

The haplotype effects of the polymorphisms on inverted papilloma risk were analyzed using Chaplin 1.2 (genetics.emory.edu) and THESIAS software (www. genecanvas.org). All haplotypes were examined simultaneously in regression models with the most common haplotype as the reference. Haplotypes were evaluated for association with IP in unadjusted and adjusted logistic regression models as for the individual SNPs. All multivariate models were adjusted for age, gender, family history, and smoking status. Reported $p$ values were two sided. Probabilities were considered significant whenever the $p$ value was lower than 0.05 . All analyses were completed using STATA software (version 11.0 Stata-Corp., Texas, USA).

\section{Results}

The distribution of socio-demographic features of the study subjects is shown in Table 1. All of the studied individuals, patients and controls were Caucasians and constituted a homogenous population from the same ethnic and geographical

Table 1 Socio-demographic of inverted papilloma cases and controls

\begin{tabular}{llll}
\hline & Cases $n(\%)$ & Controls $n(\%)$ & $p^{\mathrm{a}}$ \\
\hline Sample size & $n=130$ & $n=418$ & \\
Observation period, months & $59.37 \pm 37.63$ & $84.56 \pm 35.44$ & \\
Age, years & $59.14 \pm 12.66$ & $64.17 \pm 8.28$ & \\
$\quad<50$ years & $49(37.7)$ & $190(54.5)$ & \\
$\geq 50$ years & $81(62.3)$ & $228(45.5)$ & 0.11 \\
Gender & & & \\
$\quad$ Male & $89(68.5)$ & $314(75.1)$ & 0.13 \\
Female & $41(31.5)$ & $104(24.9)$ & \\
Family history of H\&N tumors* & & \\
$\quad$ Yes & $4(3.1)$ & $17(4.1)$ & 0.61 \\
$\quad$ No & $126(96.1)$ & $401(95.9)$ & \\
Smoking status & & & \\
Smokers (current) & $71(54.6)$ & $141(33.7)$ & $<0.001$ \\
$\quad$ Non-smokers & $59(45.4)$ & $277(66.3)$ & \\
Former & $12(9.2)$ & $155(37.1)$ & \\
Never & $47(36.2)$ & $122(29.2)$ & \\
\hline
\end{tabular}

${ }^{\mathrm{a}}$ The chi-square $\left(\chi^{2}\right)$ test

b Smoking was grouped into "current", "former" and "never" based on self-reported usage. Participants who reported smoking at least 100 cigarettes in their lifetime and who, at the time of survey, smoked either every day or some days were defined as a current smoker. Participants who reported smoking at least 100 cigarettes in their lifetime and who had not been smoking for at least 3 months were defined as a former smoker. Participants who reported never having smoked 100 cigarettes were defined as a never smoker

$H \& N$ tumors benign or malignant tumors of head and neck region 
origins. On average, the cases with identified histopathologically sinonasal inverted Schneiderian papilloma (IP) were slightly younger than controls (59.14 years \pm 12.66 vs. 64.17 years \pm 8.28 for controls) and more often qualified as current smokers (54.6 vs. $33.7 \%$ for controls). A positive family history of benign or malignant head and neck region tumors in at least one first-degree relative was mildly significant compared to controls (3.1 vs. $4.1 \%$ for controls). The clinicopathological parameters of the inverted papillomas studied are presented in Table 2. In the histological examination tumoric lesions in most cases were typed as endophytic
$(91.5 \%)$ according to the IARC WHO classification. IP cases more likely to have diffuse tumor growth, as defined by a simultaneous invasion of more anatomical sites (53.1\%) and they appeared to dominate by pT2 (58.5\%) tumors according to Krouse staging with maxillary or ethmoid anterior sinuses occupation. Mild or severe dysplasia in tumor stroma and invasive bone destruction were observed in 32.3 and $15.4 \%$ tumors, respectively. Typical histopathological features of the inverted Schneiderian papilloma showing endophytic growth of pseudostratified ciliated epithelium forming cystic spaces with and without dysplastic areas are shown in
Table 2 Clinicopathological characteristics of inverted papilloma cases

\begin{tabular}{|c|c|c|}
\hline & Variable & Cases $n(\%)$ \\
\hline \multirow[t]{8}{*}{ Symptoms } & Nasal obstruction & $64(49.2)$ \\
\hline & Rhinorhoea & $71(54.6)$ \\
\hline & Feeling of pressure & $24(18.5)$ \\
\hline & Impaired sense of smell & $50(38.5)$ \\
\hline & Pain & $20(15.4)$ \\
\hline & Epistaxis & $9(10.8)$ \\
\hline & Diploplia & $3(2.3)$ \\
\hline & None & $8(6.2)$ \\
\hline \multirow[t]{4}{*}{ Stage (Krouse classification) ${ }^{\mathrm{a}}$} & pT1 & $40(30.7)$ \\
\hline & pT2 & $76(58.5)$ \\
\hline & pT3 & $13(10.0)$ \\
\hline & pT4 (squamous cell carcinoma) & $1(0.8)$ \\
\hline \multirow[t]{3}{*}{ Histological type $\mathrm{b}^{\mathrm{b}}$} & Endophytic growth & $119(91.5)$ \\
\hline & Exophytic growth & $11(8.5)$ \\
\hline & Cylindrical cell papilloma & $0(0.0)$ \\
\hline \multirow[t]{6}{*}{ Anatomical area occupied ${ }^{\mathrm{c}}$} & Nasal cavity & 97 (74.6) \\
\hline & Maxillary sinuses & $70(53.8)$ \\
\hline & Ethmoid anterior sinuses & $43(33.1)$ \\
\hline & Ethmoid posterior sinuses & $15(11.5)$ \\
\hline & Frontal sinuses & $8(6.1)$ \\
\hline & Sphenoid sinuses & $6(4.6)$ \\
\hline \multirow[t]{2}{*}{ Anatomical sites occupied } & 1 region & $61(46.9)$ \\
\hline & More regions & $69(53.1)$ \\
\hline \multirow[t]{2}{*}{ IP with dysplasia (mild or severe) } & No & $88(67.7)$ \\
\hline & Yes & $42(32.3)$ \\
\hline \multirow[t]{2}{*}{$\mathrm{Ki} 67 \mathrm{IHC}$ staining $^{\mathrm{d}}$} & Low & $5(3.8)$ \\
\hline & High & $46(35.4)$ \\
\hline \multirow[t]{2}{*}{ Bone destruction } & No & $110(84.6)$ \\
\hline & Yes & $20(15.4)$ \\
\hline \multirow[t]{2}{*}{ Recurrences of IP } & No & $112(86.2)$ \\
\hline & Yes & $18(13.8)$ \\
\hline \multirow[t]{2}{*}{ IP associated with malignancy } & No & $129(99.2)$ \\
\hline & Yes & $1(0.8)$ \\
\hline
\end{tabular}

\footnotetext{
${ }^{a}$ Krouse staging system [28]

${ }^{b}$ The IARC WHO classification of head and neck tumors [29]

${ }^{\mathrm{c}}$ In each IP case, one or more anatomical sites may be occupied simultaneously

${ }^{\mathrm{d}}$ Low ( $<14 \%$ Ki67-positive cells); high ( $\geq 14 \%$ Ki67-positive cells)
} 
Fig. 1a-d. The locoregional recurrences were confirmed in almost $14 \%$ cases. Of the 51 cases (42 cases of dysplasia and 9 IP cases in which the histological evaluation of H\&Estained sections disclosed an increased proliferation of tumor cells), 46 (35.4\%) tumors have high IHC Ki67 index, and only 5 (3.8\%) cases were Ki67 low-stained. The representative images of low and high Ki67 immunoexpression in tissues of inverted papilloma are shown in Fig. 2a, b.

Genotype and allele distributions in the MT2A gene in 130 genetically unrelated inverted papilloma patients and 418 controls are summarized in Table 3. All genotype and allele frequencies $(-5 \mathrm{~A} / \mathrm{G},-209 \mathrm{~A} / \mathrm{G}$ and $+838 \mathrm{C} / \mathrm{G})$ were confirmed as compatible with Hardy-Weinberg equilibrium among the cases and controls, respectively (all $p>0.05$ ). As a result, only the $-5 \mathrm{~A} / \mathrm{G}$ (rs28366003) SNP in the $M T 2 A$ gene was significantly related to Schneiderian papilloma in this populationbased case-control study. The frequency of A allele carriage was 99.2 and $100 \%$ in cases and controls, respectively. The G allele carriage was detected in $24.6 \%$ of IP and in $4.1 \%$ of the non-IP samples. The respective genotype frequencies in the promoter region at locus -5 (rs28366003) were found as homozygote typical (A/A), heterozygote $(\mathrm{A} / \mathrm{G})$ and homozygote atypical $(\mathrm{G} / \mathrm{G})$ in $75.4,23.8$, and $0.8 \%$ for cases, and 95.9 , 4.1 , and $0 \%$ for controls. Likewise, genotype distribution with regard to age, gender and smoking status was found to be very similar. MT2A gene SNP in relation to age, gender, and smoking status in cases and controls are shown in Table 4. A significant interaction with gender for rs 28366003 was observed in cases $(p=0.006)$. This suggests an influence of sex on the association of $M T 2 A$ gene SNP with IP. It should be also emphasized that IP individuals with confirmed recurrences in follow-up in most cases appeared to have heterozygosity $(\mathrm{A} / \mathrm{G})$ at locus $-5(\mathrm{rs} 28366003)(55.6 \%)$. The homozygote typical (A/A) constituted only $44.4 \%$ of all these cases. Mild or severe dysplasia was observed in 47.6 and $52.4 \%$ carriers of the $\mathrm{G}$ and A allele, respectively. All cases with low IHC Ki67 index were individuals with A/A genotype. Bone destruction was confirmed in $55 \%$ of individuals with one copy of the risk allele $(\mathrm{G})$ at locus -5 (rs28366003) MT2A and in $45 \%$ of typical homozygotes. Malignant transformation into squamous cell carcinoma also concerned individuals with an $\mathrm{A} / \mathrm{G}$ genotype.

Our findings reinforce the association of MT2A (rs28366003) with the risk of Schneiderian papilloma. In the study population, the pathogenic link between the rs 1610216 and rs 10636 variants and this type of tumor was excluded. The genetic association analysis revealed that the presence of $\mathrm{A} / \mathrm{G}$ allele at $M T 2 A$ gene were at higher risk with an approximately 7.4-fold increase for the development of sinonasal inverted papilloma (odds ratio $[\mathrm{OR}]=7.43 ; 95 \%$ confidence interval [CI], 3.91-14.46; $p<0.001)$. Moreover, confirmation of one copy of the risk allele $(\mathrm{G})$ at locus -5 (rs28366003) of the core promoter region of $M T 2 A$ gene conferred an estimated increase in Schneiderian papilloma of almost 7.7-fold in the model adjusted for age, gender, family history and smoking status $\left(\mathrm{OR}=7.71 ; 95 \% \mathrm{CI}, 4.01-14.91, p_{\text {dominant }}<0.001\right)$. Individuals with $\mathrm{A} / \mathrm{A}$ genotype have a protective effect against IP development. Four MT2A haplotypes were shown to have a population frequency of at least $5 \%$. Interestingly, of the four coding variants found solely in IP patients, a three-locus haplotype (G-A-G) including the rs28366003 SNP variant allele of the $M T 2 A$ gene was found to be significantly associated with a $16 \%$ increased risk of inverted papilloma $(\mathrm{OR}=$ $1.16 ; 95 \%$ CI, $0.74-1.94, p_{\text {global }}=0.02$ ). The association between MT2A haplotypes and statistical analysis results of Schneiderian papilloma risk are shown in Table 5.
Fig. 1 Inverted papilloma without dysplasia $(\mathrm{H} \& \mathrm{E}, \times 200$ magnification) (a), inverted papilloma without dysplasia and prominent stromal edema (H\&E, $\times 200$ magnification) (b), inverted papilloma with mild dysplasia and signs of viral infection (H\&E, $\times 200$ magnification) $(\mathbf{c})$, inverted papilloma with severe dysplasia (H\&E, $\times 200$ magnification) (d)

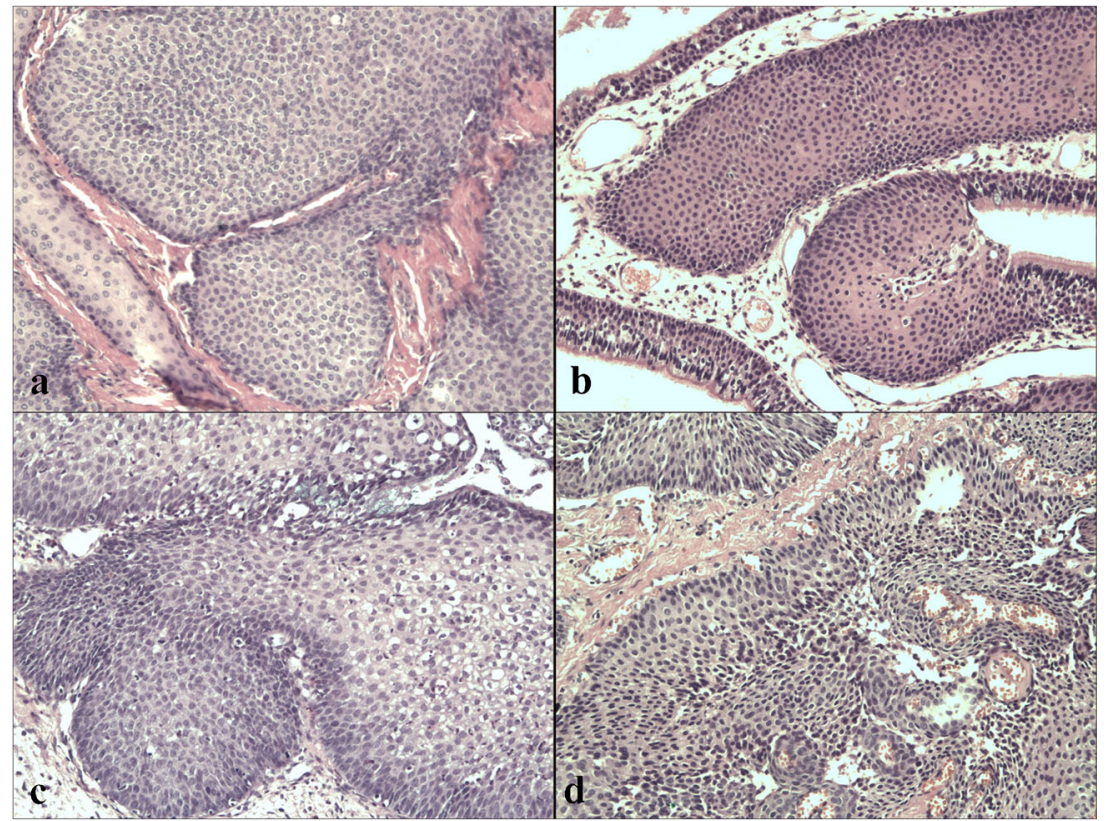




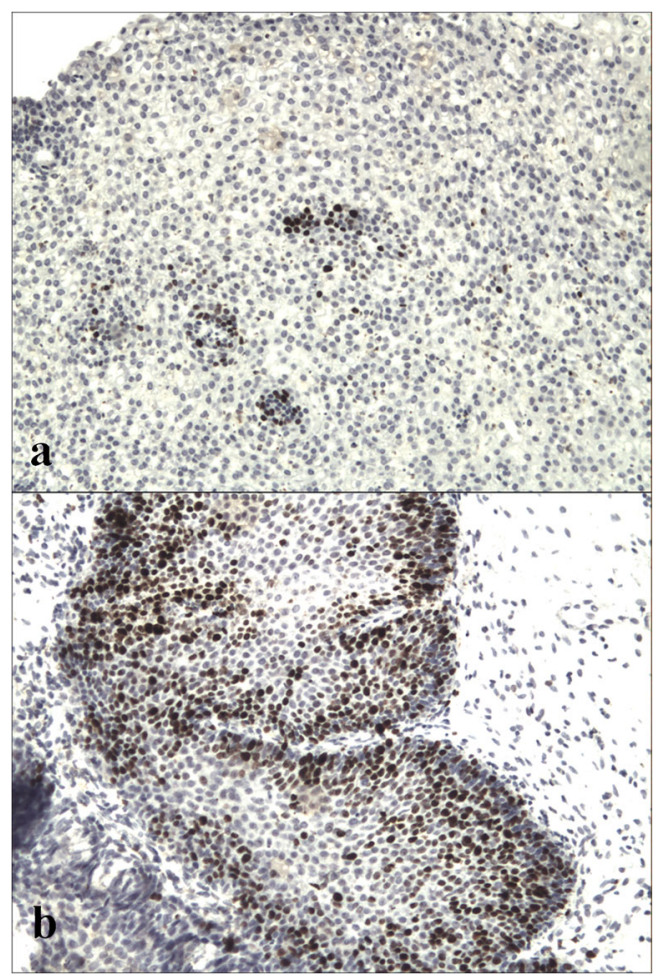

Fig. 2 Ki67 immunohistochemistry (IHC): the low immunoexpression of Ki67 in inverted papilloma without dysplasia ( $\times 100$ magnification $)(a)$, the high immunoexpression of Ki67 in inverted papilloma with severe dysplasia $(\times 100$ magnification $)(\mathbf{b})$

Since a significant association was confirmed between -5 $\mathrm{A} / \mathrm{G}$ SNP and the risk of inverted papilloma, it was investigated whether genetic variation identified in the core promoter region can affect tumor behavior, as defined by morphological evaluation. The SNP at locus -5 (rs28366003) was also found to be associated with IP phenotype in a Polish population. The heterozygotes of the major allele and atypical homozygotes appeared to have higher Krouse stage (pT1 vs. pT2-4) $(\mathrm{OR}=$ $19.32 ; 95 \%$ CI, 2.30-173.53; $p<0.0001)$, more diffuse tumor growth, as defined by a simultaneous occupation of more anatomical sites $(\mathrm{OR}=4.58 ; 95 \% \mathrm{CI}, 1.70-12.11 ; p=$ $0.0008)$ and bone destruction $(\mathrm{OR}=4.13 ; 95 \% \mathrm{CI}, 1.50$ $11.60 ; p=0.003)$. A similar significant association was determined for the risk allele carriage with regard to higher incidence of tumor recurrences in follow-up $(\mathrm{OR}=5.11 ; 95 \% \mathrm{CI}$, $1.68-15.20 ; p=0.001)$. Confirmation of one copy of the risk allele $(\mathrm{G})$ in the core promoter region of $M T 2 A$ gene conferred an estimated five-fold increase in local relapse of neoplastic process. The associations between clinicopathological characteristics and papilloma inverted risk are shown in Table 6.

\section{Discussion}

The present work evaluates the effect of genetic polymorphisms in the MT2A core promoter region on the risk and tumor behavior of sinonasal Schneiderian papilloma in a Polish population. It should be emphasized that, at the time of writing, no publication has yet analyzed the SNPs of MT2A in relation to human inverted papilloma susceptibility. Moreover, this is also the first study to investigate the expression of MT2A isoforms in IP biopsy tissue and to document the relationship between MT2A SNPs and aggressive phenotype of this type of head and neck tumor. Therefore, our findings may only be compared with those of studies carried out for other types of head and neck cancers or human neoplasms in other localizations. It should also be noted that, to our knowledge, the material studied constitutes the largest homogeneous group of these benign, locally aggressive head and neck tumors which share both the same tissue origin and histological type according to the IARC WHO classification. This is an additional value of this research, when the difficulties in obtaining such rare pathological material collected over many years are taken into consideration. Because of these constraints, an overwhelming proportion of inverted papilloma research has used only paraffin-embedded archival material, often histologically heterogenous and thus limited in number, with fewer than fifty cases being included in most studies. The limitations described doubtlessly have an impact on the final results and the data interpretation in terms of the mechanisms of the tumorigenesis of this neoplastic lesion. Hence, greater knowledge of the SNPs of MT2A and their relationship with human inverted papilloma tumorigenesis and behavior is needed to elucidate the biological functions of metallothioneins in this neoplastic process, and to determine their possible clinical significance as biomarker of the dynamics of tumor growth, invasiveness, and prognosis. Three analyzed SNPs that could potentially affect $M T 2 A$ gene expression were selected on the basis of a literature review.

In recent years, the possible role of various metallothionein isoforms and polymorphisms on physiological and pathological processes has been documented $[6,10,30]$. Since the expression of MTs can be affected by genetic variation in the core promoter region and diverse frequency of the essential alleles, the presence of SNPs may lead to reduced cellular activity of metallothioneins and affect abnormal intracellular pathways of cell proliferation, apoptosis, and response to oxidative stress, thus potentially influencing the susceptibility of the individual to various types of tumors [6, 8, 20-22, 31-33]. Unfortunately, among the several previous reports on the rs28366003, rs1610216, and rs10636 SNPs in the MT2A gene, only single studies related to the neoplastic process report the frequency of MT isoforms within different ethnic populations [20-23, 34-38].

Our study documents for the first time the genetic association between the occurrence of $-5 \mathrm{~A} / \mathrm{G}$ SNP in the core promoter region of the $M T 2 A$ gene and the risk of sinonasal inverted papilloma, as well as the dynamics of tumor growth according to Krouse staging, a precise, multifactorial 
Table 3 Associations between MT2A SNPs and inverted papilloma risk

\begin{tabular}{|c|c|c|c|c|c|}
\hline SNP genotype & Cases $(\%) /$ controls $(\%)$ & OR $(95 \% \mathrm{CI})^{\mathrm{a}}$ & $p$ & OR $(95 \% \mathrm{CI})^{\mathrm{b}}$ & $p$ \\
\hline \multicolumn{6}{|l|}{ rs 28366003} \\
\hline AA & $98(75.4) / 401(95.9)$ & 1.00 (reference) & & 1.00 (reference) & \\
\hline $\mathrm{AG}$ & $31(23.8) / 17(4.1)$ & $7.46(3.84-14.47)$ & $<0.001$ & $7.43(3.91-14.46)$ & $<0.001$ \\
\hline GG & $1(0.8) / 0(0.0)$ & - & & & \\
\hline$p$ trend $^{\mathrm{c}}$ & $<0.0001$ & & & & \\
\hline AG or GG vs. $A^{d}$ & $32(24.6) / 17(4.1)$ & $7.70(3.97-14.91)$ & $<0.001$ & $7.71(4.01-14.91)$ & $<0.001$ \\
\hline $\mathrm{AG}$ or $\mathrm{AA}$ vs. $\mathrm{GG}^{\mathrm{e}}$ & $129(99.2) / 418(100.0)$ & - & & - & \\
\hline \multicolumn{6}{|l|}{ rs 1610216} \\
\hline AA & $96(73.8) / 309(73.9)$ & 1.00 (reference) & & 1.00 (reference) & \\
\hline $\mathrm{AG}$ & $33(25.4) / 106(25.3)$ & $1.00(0.64-1.58)$ & 0.99 & $1.01(0.66-1.58)$ & 0.99 \\
\hline GG & $1(0.8) / 3(0.8)$ & $1.07(0.11-10.46)$ & 0.95 & $1.07(0.10-10.44)$ & 0.94 \\
\hline$p$ trend $^{\mathrm{c}}$ & 0.97 & & & & \\
\hline AG or GG vs. $A^{d}$ & $34(26.1) / 109(26.1)$ & $1.00(0.64-1.57)$ & 0.99 & $0.99(0.61-1.56)$ & 0.99 \\
\hline AG or AA vs. $G^{\mathrm{e}}$ & $129(99.2) / 415(99.3)$ & $1.07(0.11-10.42)$ & 0.95 & $1.07(0.13-10.42)$ & 0.95 \\
\hline \multicolumn{6}{|l|}{ rs 10636} \\
\hline GG & $58(44.6) / 213(50.9)$ & 1.00 (reference) & & 1.00 (reference) & \\
\hline GC & $56(43.1) / 172(41.2)$ & $1.19(0.78-1.82)$ & 0.40 & $1.23(0.72-1.82)$ & 0.40 \\
\hline $\mathrm{CC}$ & $16(12.3) / 33(7.90)$ & $1.78(0.91-3.47)$ & 0.09 & $1.78(0.94-3.47)$ & 0.09 \\
\hline$p$ trend $^{\mathrm{c}}$ & 0.1 & & & & \\
\hline $\mathrm{GC}$ or $\mathrm{CC}$ vs. $\mathrm{GG}^{\mathrm{d}}$ & $72(55.4) / 205(49.0)$ & $1.29(0.87-1.92)$ & 0.21 & $1.30(0.87-1.95)$ & 0.22 \\
\hline $\mathrm{GC}$ or GG vs. $\mathrm{CC}^{\mathrm{e}}$ & $114(87.7) / 385(92.1)$ & $1.64(0.87-3.09)$ & 0.12 & $1.65(0.83-3.10)$ & 0.13 \\
\hline
\end{tabular}

${ }^{a}$ Crude

${ }^{\mathrm{b}}$ Adjusted for age, gender, family history and smoking status

${ }^{\mathrm{c}}$ Testing additive genetic model (Cochran-Armitage test for trend)

d Testing dominant genetic model

${ }^{\mathrm{e}}$ Testing recessive genetic model

Table $4 M T 2 A$ gene $-5 \mathrm{~A} / \mathrm{G}$ rs28366003 polymorphism in relation to age, gender and smoking status in an inverted papilloma (cases) and nonpapilloma cases (controls)

\begin{tabular}{|c|c|c|c|c|c|}
\hline \multirow[t]{2}{*}{ Variable } & & \multicolumn{3}{|l|}{ Genotype $n(\%)$} & \multirow[t]{2}{*}{$p^{\mathrm{a}}$} \\
\hline & & $\mathrm{A} / \mathrm{A}$ & $\mathrm{A} / \mathrm{G}$ & $\mathrm{G} / \mathrm{G}$ & \\
\hline \multicolumn{6}{|l|}{$\mathrm{IP}$ — cases } \\
\hline \multirow[t]{2}{*}{ Age } & $\begin{array}{l}<50 \text { years }(n=49) \\
\geq 50 \text { years }(n=81)\end{array}$ & $\begin{array}{l}40(30.8) \\
58(44.6)\end{array}$ & $\begin{array}{r}8(6.1) \\
23(17.7)\end{array}$ & $\begin{array}{l}1(0.8) \\
0(0.0)\end{array}$ & 0.42 \\
\hline & $\begin{array}{l}<50 \text { years }(\text { years } \pm S D) \\
\geq 50 \text { years }(\text { years } \pm S D)\end{array}$ & $\begin{array}{l}47.9 \pm 15.8 \\
62.1 \pm 13.9\end{array}$ & $\begin{array}{l}46.8 \pm 12.34 \\
52.0 \pm 16.5\end{array}$ & $\begin{array}{r}47 \\
-\end{array}$ & - \\
\hline Gender & $\begin{array}{l}\text { Male }(n=89) \\
\text { Female }(n=41)\end{array}$ & $\begin{array}{l}59(45.4) \\
39(30.0)\end{array}$ & $\begin{array}{r}29(22.3) \\
2(1.5)\end{array}$ & $\begin{array}{l}1(0.8) \\
0(0.0)\end{array}$ & 0.006 \\
\hline Smoking status & $\begin{array}{l}\text { Smokers }(n=71) \\
\text { Non-smokers }(n=59)\end{array}$ & $\begin{array}{l}51(39.2) \\
47(36.1)\end{array}$ & $\begin{array}{r}19(14.6) \\
12(9.2)\end{array}$ & $\begin{array}{l}1(0.9) \\
0(0.0)\end{array}$ & 0.77 \\
\hline \multicolumn{6}{|l|}{ non-IP_controls } \\
\hline \multirow[t]{2}{*}{ Age } & $\begin{array}{l}<50 \text { years }(n=190) \\
\geq 50 \text { years }(n=228)\end{array}$ & $\begin{array}{l}185(44.2) \\
216(51.7)\end{array}$ & $\begin{array}{r}5(1.2) \\
12(2.9)\end{array}$ & $\begin{array}{l}0(0.0) \\
0(0.0)\end{array}$ & 0.17 \\
\hline & $\begin{array}{l}<50 \text { years }(\text { years } \pm S D) \\
\geq 50 \text { years }(\text { years } \pm S D \text { ) }\end{array}$ & $\begin{array}{l}53.1 \pm 14.6 \\
67.3 \pm 12.5\end{array}$ & $\begin{array}{l}46.2 \pm 11.4 \\
51.1 \pm 12.1\end{array}$ & $\begin{array}{l}- \\
-\end{array}$ & - \\
\hline Gender & $\begin{array}{l}\text { Male }(n=314) \\
\text { Female }(n=104)\end{array}$ & $\begin{array}{r}305(73.0) \\
96(23.0)\end{array}$ & $\begin{array}{l}9(2.1) \\
8(1.9)\end{array}$ & $\begin{array}{l}0(0.0) \\
0(0.0)\end{array}$ & 0.03 \\
\hline Smoking status & $\begin{array}{l}\text { Smokers }(n=141) \\
\text { Non-smokers }(n=277)\end{array}$ & $\begin{array}{l}128(30.6) \\
273(65.3)\end{array}$ & $\begin{array}{r}13(3.1) \\
4(1.0)\end{array}$ & $\begin{array}{l}0(0.0) \\
0(0.0)\end{array}$ & 0.0001 \\
\hline
\end{tabular}

${ }^{\mathrm{a}}$ The chi-square $(\chi 2)$ test 
Table 5 Associations between $M T 2 A$ haplotypes and inverted papilloma risk

\begin{tabular}{llll}
\hline Haplotypes (SNP1-SNP3) & Cases (\%)/controls $(\%)$ & OR $(95 \% \mathrm{CI})^{\mathrm{a}}$ & OR $(95 \% \mathrm{CI})^{\mathrm{b}}$ \\
\hline A-A-G & $53(40.8) / 133(31.8)$ & $1.00($ reference $)$ & 1.00 (reference) \\
G-A-G & $41(31.5) / 87(20.8)$ & $1.18(0.72-1.93)$ & $1.16(0.74-1.94)$ \\
A-A-C & $21(16.1) / 104(24.9)$ & $0.51(0.28-0.89)$ & $0.49(0.27-0.89)$ \\
A-G-C & $15(11.6) / 94(22.5)$ & $0.40(0.21-0.76)$ & $0.40(0.24-0.75)$ \\
\hline${ }^{\text {a Crude }}$ & & \\
${ }^{\mathrm{b}}$ Adjusted for age, gender, family history, and smoking status &
\end{tabular}

histological analysis of biopsy material and incidence of recurrences. The harvested data indicates that a positive relationship exists between (rs28366003) SNP and both higher susceptibility and increased invasiveness of Schneiderian papilloma in Polish inhabitants.

As a result, the genotype frequencies in the core promoter region at locus $-5 \mathrm{~A} / \mathrm{G}$ (rs28366003) were found to be homozygote typical (A/A) in $75.4 \%$, heterozygote $(\mathrm{A} / \mathrm{G})$ in $23.8 \%$ and homozygote atypical $(\mathrm{G} / \mathrm{G})$ in $0.8 \%$ individuals with sinonasal inverted papilloma. Our recent study has also reported a similar prevalence of $\mathrm{A}$ by $\mathrm{G}$ replacement at position -5 in the core region of the MT2A promoter for homozygous common allele carriers as well as for heterozygosity and homozygosity for the $\mathrm{G}$ variant in the studied IP group [39]. The resulting data resemble the findings in some ethnic populations such as those from Japan, Turkey, and America [23, 36-38]. For example, Kita et al. [23] report that an incidence of the conversion $\mathrm{A} \rightarrow \mathrm{G}$ in the core promoter region of the $M T 2 A$ gene near the TATA box was $18 \%$ for Japanese people, with the carriage of different genotypes being 82,17 , and $0.9 \%$ for A/A, A/G, and G/G, respectively. Similar results were detected by Kayaalti and Söylemezoğlu [37] within a Turkish population, wherein the genotype frequencies of -5 A/G SNP were observed as homozygote typical in $87 \%$, heterozygote in $12.3 \%$, and homozygote atypical in $0.7 \%$ individuals. In another study, the same researchers observe a high dependence of MT2A core promoter gene polymorphisms with aging and conclude that absence of a risk allele variant $(G)$ may be associated with better survival [36]. Similarly, McElroy et al. [38] demonstrated the allele $\mathrm{G}$ was not frequent genetic variation at rs28366003 in MT2A gene in black and white female volunteers in the Midwestern United States. In this population, the prevalence of the minor allele was found to be $6.4 \%$ for white and $1.1 \%$ for black individuals.

The data concerning MT2A genotype frequencies identified in the different neoplastic processes were also found to be very similar to our results: the most frequent genotype was $\mathrm{A} / \mathrm{A}$, while heterozygosity and homozygosity for the risk $\mathrm{G}$ variant was less so [20-22]. The genotype distributions of MT2A (rs28366003) SNP in prostate cancer and breast cancer described by Krześlak et al. [20, 21] confirm those given in the present study and were found to be $\mathrm{A} / \mathrm{A}$ in $76 \%, \mathrm{~A} / \mathrm{G}$ in $21.1 \%, \mathrm{G} / \mathrm{G}$ in $2.9 \%$ and $\mathrm{A} / \mathrm{A}$ in $87.1 \%, \mathrm{~A} / \mathrm{G}$ in $12.3 \%$, $\mathrm{G} / \mathrm{G}$ in $0.6 \%$ in prostate and breast cancer cases, respectively.

The present study documents the contribution of the -5 A/G single-nucleotide polymorphism in the $M T 2 A$ gene toward the risk of developing inverted papilloma in a Polish

Table 6 Associations between clinicopathological characteristics and papilloma inverted risk

\begin{tabular}{|c|c|c|c|c|c|c|}
\hline \multirow[t]{2}{*}{ Variable } & \multicolumn{2}{|l|}{ SNP rs28366003 } & \multirow[t]{2}{*}{ OR $(95 \% \mathrm{CI})^{\mathrm{a}}$} & \multirow[t]{2}{*}{$p$} & \multirow[t]{2}{*}{ OR $(95 \% \mathrm{CI})^{\mathrm{b}}$} & \multirow[t]{2}{*}{$p$} \\
\hline & AA $n(\%)$ & AG or GG $n(\%)$ & & & & \\
\hline Stage (Krouse system) pT1 vs. pT2-T4 & $39(30.0) / 59(45.4)$ & $1(0.8) / 31(23.8)$ & $20.49(2.34-179.64)$ & $<0.0001$ & $19.32(2.30-173.53)$ & $<0.0001$ \\
\hline Histological type exo vs. endophytic & $11(8.5) / 87(66.9)$ & $2(1.5) / 30(23.1)$ & $1.89(0.39-9.14)$ & 0.41 & $1.87(0.40-9.14)$ & 0.42 \\
\hline Anatomical area ${ }^{c} \mathrm{NS} / \mathrm{M} / \mathrm{EA}$ vs. EP/F/S & $81(62.3) / 17(13.1)$ & $22(16.9) / 10(7.7)$ & $2.16(0.86-5.47)$ & 0.09 & $2.15(0.86-5.39)$ & 0.08 \\
\hline Anatomical sites 1 region vs. more & $55(42.3) / 43(33.1)$ & $7(5.4) / 25(19.2)$ & $4.57(1.72-12.11)$ & 0.0008 & $4.58(1.70-12.11)$ & 0.0008 \\
\hline Dysplasia no vs. yes (mild/severe) & $76(58.5) / 22(16.9)$ & $12(9.2) / 20(15.4)$ & $2.13(0.92-4.90)$ & 0.07 & $2.14(0.97-4.91)$ & 0.07 \\
\hline Bone destruction no vs. yes & $85(65.4) / 9(6.9)$ & $25(19.2) / 11(8.5)$ & $4.15(1.49-11.60)$ & 0.003 & $4.13(1.50-11.60)$ & 0.003 \\
\hline Recurrences no vs. yes & $90(69.2) / 8(6.2)$ & $22(16.9) / 10(7.7)$ & $5.11(1.71-15.21)$ & 0.001 & $5.11(1.68-15.20)$ & 0.001 \\
\hline
\end{tabular}

${ }^{a}$ Crude, AA vs. AG or GG MT2A SNP rs28366003 (the homozygote of the common allele were estimated as the reference group)

${ }^{\mathrm{b}}$ Adjusted for age, gender, family history and smoking status

${ }^{\mathrm{c}}$ In NS/M/EA cases only nasal cavity, maxillary sinuses and/or ethmoid anterior sinuses were occupied; In EP/F/S cases besides nasal cavity, maxillary sinuses and/or ethmoid anterior sinuses the other anatomical sites such as ethmoid posterior sinuses, frontal sinuses and/or sphenoid sinuses were occupied simultaneously ( $N C$ nasal cavity, $M$ maxillary sinuses, $E A$ ethmoid anterior sinuses, $E P$ ethmoid posterior sinuses, $F$ frontal sinuses, $S$ sphenoid sinuses) 
population. It was also determined that confirmation of one copy of the risk allele $(\mathrm{G})$ at locus -5 (rs28366003) of the core promoter region of $M T 2 A$ gene conferred 7.7-fold increase in Schneiderian papilloma risk in a model adjusted for age, gender, family history, and smoking status.

Unfortunately, as a literature survey revealed no publication describing a genetic implication of MT2A SNPs in the pathogenesis of head and neck tumors, the harvested results can only be compared to our previous reports in laryngeal cancer $[18,19]$. The results indicate that the presence of an $\mathrm{SNP}$ in the core promoter region at locus $-5 \mathrm{~A} / \mathrm{G}$ (rs28366003) in the MT2A gene contributes to a higher risk of malignant head and neck tumors.

It should be also added that only a few studies found in the literature concern metallothionein genetic variations in relation to pathological mechanisms, as well as to the development, tumor behavior, and progression of other neoplastic lesions [20-22, 31-33]. The studies indicate that MT2A core promoter region genetic polymorphism and in particular confirmation although of one copy of the risk allele at rs 28366003 in the $M T 2 A$ gene may have an impact on cancer risk of various origins. In this context, our findings for sinonasal inverted papilloma resemble the findings in other cancers. Aberrant MT expression due to altered transcription at the core promoter region of the $M T 2 A$ gene, as a reason of enhanced sensitivity for the carcinogenic heavy metals and metallic agents and deregulation of cell proliferation and inhibition of apoptosis, have been discussed [5, 20-22, 32, 33]. For example, Forma et al. [22] demonstrated almost 1.3- and 4.3-fold greater risks of primary prostate cancer associated with SNP in MT2A (rs28366003) linked to heterozygosity and homozygosity for the risk $\mathrm{G}$ allele, respectively, in the model adjusted for age. A similar result was reported by Krześlak et al. [21] for the same type of cancer in which a 2.6-fold increase in risk in heterozygous $\mathrm{G}$ allele carriers compared to individuals who were homozygous for allele A was established. Moreover, it was demonstrated that enhanced susceptibility to neoplasm was related to aberrant expression of MT2A and $\mathrm{Cd}, \mathrm{Zn}, \mathrm{Cu}$, and $\mathrm{Pb}$ content in biopsy neoplastic tissue. In another study, the same researchers also observed an increase of almost $90 \%$ in the risk of ductal breast cancer after adjustment for inter alia age, family history, smoking status, menarche and menopausal status in subjects having one copy of the risk $G$ allele in MT2A promoter region as well as an increase of $50 \%$ in risk of cancer when MT2A haplotypes G-A-G was taken into account. An association between other MT2A SNPs and susceptibility to tumorigenesis was also detected, confirming several previous reports. For instance, Seibold et al. [32, 33] documented a significant modification of post-menopausal breast cancer risk per specific alleles of six polymorphisms, including SNP in MT2A (rs1580833) and its association with the overall mortality of the subjects. Regardless of different types of cancers discussed in the literature, the findings are in line with other research suggesting potential role of MT2A SNP in determining the risk of neoplastic process.

Since the conversion of nucleotides $\mathrm{A}$ to $\mathrm{G}$ in the core promoter region of $M T 2 A$ gene may affect the MT gene transcription induced by heavy metals and metallic agents and consequently lead to higher sensitivity to metal toxicity, the risk of tumors of various origin due to SNP has been evaluated in certain tumors [5, 20-23]. The direct functional connections and an understanding of the specific mechanisms through which the SNP in the MT2A gene regulate toxic metal concentrations as potential carcinogenic factors and influence tumor cell dynamics and pathology have been reported in only a few publications and remain elusive [5, 8, 20, 33-35, 40-42]. The study by Kayaalti et al. [34] provides evidence implicating MT2A SNP polymorphisms on heavy metal expression in the blood samples taken from a Turkish population. A confirmation of homozygosity for the risk allele variant $(\mathrm{G})$ at locus -5 (rs28366003) in MT2A gene determined higher $\mathrm{Cd}$ and $\mathrm{Pb}$ concentration compared with $\mathrm{A} / \mathrm{A}$ and $\mathrm{A} / \mathrm{G}$ genotypes, as well as higher sensitivity for heavy metal toxicity. However, in contrast to the present study, the same authors report that certain genetic variations such as heterozygosity and atypical homozygosity influence higher accumulation of Cd in autopsy kidney tissues, but no association was found between $-5 \mathrm{~A} / \mathrm{G}$ $\mathrm{SNP}$ and both $\mathrm{Zn}$ and $\mathrm{Cu}$ levels in the renal cortex [35]. Also, Tekin et al. [43] observed the implication of $A / G$ genotype carriage in the MT2A promoter region on the increased $\mathrm{Pb}$ concentration in blood samples and placental tissue in pregnant women and the risk of low-level cord blood lead variation in their newborns. The harvested data resemble our recent findings in inverted papilloma, in which a significant connection was observed between rs 28366003 and a considerably high accumulation of both $\mathrm{Cd}$ and $\mathrm{Cu}$ in biopsy tissue [39]. These changes in toxic metal levels in neoplastic tissue remain in line with our previous studies on laryngeal cancer, which note that $-5 \mathrm{~A} / \mathrm{G}$ SNP in the $M T 2 A$ gene may be related to $\mathrm{Cd}$, $\mathrm{Zn}$, and $\mathrm{Cu}$ content [18].

Our study also documents the relationship between the SNPs in the MT2A gene and the dynamics of tumor growth, according to a thorough multifactorial histological evaluation of inverted papillomas. The current data confirms that the carriage of the risk allele $(\mathrm{G})$ was associated with increased tumor invasiveness according to Krouse grading, and a higher incidence of recurrences when compared with typical homozygous patients. This data is also confirmed by our previous study of laryngeal cancers, which notes that -5 (rs28366003) of the core promoter region of $M T 2 A$ gene was found to exert issue impact on malignant tumor behavior [19].

Unfortunately, a literature search indicates that no studies have yet been performed on the relationship between SNPs at rs28366003 MT2A and phenotype of aggressiveness in tumors of the head and neck region. However, some studies have linked MT isoform function to neoplastic cell dynamics 
and tumor pathology in other neoplasms, yet findings remain limited and often divergent, especially regarding the impact of their specific isoforms on tumor invasion and prediction of patient outcome [5, 10, 20-23]. Most researchers have confirmed increased expression of MT1 and MT2 and a positive association of these isoforms with standard clinical parameters such as higher pTNM classification, higher stage, lower histological differentiation as well as chemotherapy and radiation resistance and shorter survival time. However, MT expression does not affect the clinical disease parameters and mortality in other types of tumors, i.e., hepatocellular, gastric, colorectal, central nervous system, and thyroid cancers [10, 25, 44].

Nevertheless, contrary results for MT expression related to tumor behavior, chemo-, and radiotherapy response and prognosis in head and neck neoplasms have also been reported in a few available studies [10, 26, 27, 45]. For instance, Pedersen et al. [10] report increased expression of MT1 and MT2 isoforms in human head and neck primary cancers of the nasopharynx, salivary gland, thyroid, and larynx. Also, Theocharis et al. [26] determined the impact of MT cellular distribution in either the tumor itself, or adjacent epithelial mucosa tissue on the development and progression of mobile tongue cancer. The authors note that the occurrence of positive MT expression is frequently characteristic of tumors with lower histological grade, vascular invasion, deep infiltration, and the existence of lymph node metastases. Similarly, Gumulec et al. [14] estimate a positive association of MT immunoexpression with advanced tumor grade and shorter patient survival in head and neck malignant tumors. By contrast, other researchers have not confirmed that MT expression corresponds to clinicomorphological parameters in tumors of the head and neck region [27, 45]. For example, Pastuszewski et al. [27] document the opposite findings in laryngeal carcinomas. In this case, MT expression was found to be not significantly related to the tumor grade, stage or clinical outcome parameters. The results described by Dutsch-Wicherek et al. [45] were almost the same as those given in the mentioned study. MT staining in tumor infiltration was lower than in peri-tumor stroma tissue and has been found not to be associated with nodal metastases in head and neck cancer and breast adenocarcinoma population. The researchers suggest that MT expression may be due to a protective reaction of healthy noncancerous tissue to the tumor antigens.

In addition, a literature review reveals a wide range of findings concerning MT expression also identified in other types of neoplastic lesion. Most of the data indicate that MT2A transcripts or, most often, protein expression in tumors may be involved in determining aggressive tumor behavior and increased patient mortality, however, many demonstrate equivocal results and divergent conclusions [16, 17, 25, 44, 46-48]. For example, Werynska et al. [48] report enhanced MT2A isoform expression in a studied population of nonsmall cell lung cancer cases, and identify a positive association between MT immunostaining and primary tumor size, grade of malignancy and poor prognosis. Similarly, Kobierzycki et al. [46] observe MT1/MT2 cytoplasmic overexpression in neoplastic tissues in ovarian cancer and conclude these proteins can be predictive markers for advanced stage. Also, Habel et al. [16] indicate that higher MT2A level may also correspond to lower mortality rate and has an effect on chemoresistance to cytotoxic drugs in patients treated with osteosarcoma. A similar result was reported by Gumulec et al. [25] for prostate cancer model. In this study, upregulation of MT2A at the protein level was established to be involved in CDDP resistance. However, Gansukh et al. [44] demonstrate no significant correlation between MT expression and cisplatin sensitivity in non-small cellular lung cancer. Liang et al. [47] also suggest that the downregulation of MT2A gene level, rather than increased MT expression, may play the key role in lung carcinogenesis. Similarly, Pan et al. [17] suggest that MT2A exerts tumor suppressive activity and observe that decreased MT2A expression in cell lines and primary tumors correlates with advanced clinical stage and poor prognosis in gastric cancer.

It should be also emphasized that there are several limitations of our study and constraints in interpreting results concerning the metallothionein 2A activity and MT2A SNPs in tumorigenesis and neoplastic progression. While the -5 (rs28366003) SNP in the MT2A gene could be considered as a potential biomarker for the etiopathology and a higher susceptibility of sinonasal inverted papilloma, as well as an indicator of the dynamics of tumor growth, discrepancies shown in the discussion exist for other neoplastic lesions due to variation of tumor origins, proliferation, and histological differentiation status, which cause differences in their biology. It should be also stressed that the difficulties in obtaining human autopsy materials and using cell culture or laboratory animal material, as well as the diversity of tissues used (fresh tumor samples, cell lines, or blood), may affect the final results of research. Moreover, the relatively small size and heterogeneity of groups studied, the small proportion of homozygote atypical, and variety of analyzed populations can influence the resulting odds ratio estimates and may cause difficulties in the interpretation of results.

Our study provides evidence for implicating MT2A polymorphisms in the development of sinonasal inverted papilloma. The findings also illustrate the key role played by the rs28366003 SNP in the $M T 2 A$ gene in inducing an aggressive Schneiderian papilloma phenotype. These observations provide future possible targets for diagnosis and novel therapeutic strategies for inhibition of tumorigenesis, growth, and progression of this locally aggressive process. However, we realize that our findings represent only one voice in an ongoing discussion and further studies of greater dimensions are required to determine the precise role of MT2A in the carcinogenicity and physiopathology of neoplastic diseases. 


\section{Conclusions}

In conclusion, despite the limitation discussed, accumulating evidence indicates that the genetic variation of $M T 2 A$ may contribute to the pathogenesis of sinonasal Schneiderian inverted papilloma in a Polish population. The identification of these tumor-related $-5 \mathrm{~A} / \mathrm{G}$ (rs28366003) $M T 2 A$ gene polymorphisms could also be concerned with the more aggressive local behavior of inverted papilloma cases and used as a potential prognostic biomarker

Acknowledgments This work was supported, in part, by the statutory fund of the Department of Cytobiochemistry, University of Łódź, Poland (506/811) and by grant from the National Science Council, Poland (N403 $04332 / 2326)$.

\section{Conflicts of interest None}

Open Access This article is distributed under the terms of the Creative Commons Attribution 4.0 International License (http:// creativecommons.org/licenses/by/4.0/), which permits unrestricted use, distribution, and reproduction in any medium, provided you give appropriate credit to the original author(s) and the source, provide a link to the Creative Commons license, and indicate if changes were made.

\section{References}

1. Gu FM, Zhang LS. Clinical outcomes of endoscopic and open resection of recurrent sinonasal inverted papilloma. J Craniofac Surg. 2014;25:1090-3.

2. Wood JW, Casiano RR. Inverted papillomas and benign nonneoplastic lesions of the nasal cavity. Am J Rhinol Allerg. 2012;26:157-63.

3. Govindaraj S, Wang H. Does human papilloma virus play a role in sinonasal inverted papilloma? Curr Opin Otolaryngol Head Neck Surg. 2014;22(1):47-51.

4. D'Errico A, Zajacova J, Cacciatore A, Baratti A, Zanelli R, Alfonzo $\mathrm{S}$, et al. Occupational risk factors for sinonasal inverted papilloma: a case-control study. Occup Environ Med. 2013;70(10):703-8.

5. Mehus AA, Muhonen WW, Garrett SH, Somji S, Sens DA, Shabb JB. Quantitation of human metallothionein isoforms: a family of small, highly conserved, cysteine-rich proteins. Mol Cell Proteomics. 2014;13(4):1020-33

6. Raudenska M, Gumulec J, Podlaha O, Sztalmachova M, Babula P, Eckschlager T, et al. Metallothionein polymorphisms in pathological processes. Metallomics. 2014;6(1):55-68.

7. Babula P, Masarik M, Adam V, Eckschlager T, Stiborova M, Trnkova L, et al. Mammalian metallothioneins: properties and functions. Metallomics. 2012;4(8):739-50.

8. Qiao X, Ma ZY, Shao J, Bao WG, Xu JY, Qiang ZY, et al. Biological evaluation of a cytotoxic 2-substituted benzimidazole copper(II) complex: DNA damage, antiproliferation and apoptotic induction activity in human cervical cancer cells. Biometals. 2014;27:155-72.

9. Juang HH, Chung LC, Sung HC, Feng TH, Lee YH, Chang PL, et al. Metallothionein 3: an androgen-upregulated gene enhances cell invasion and tumorigenesis of prostate carcinoma cells. Prostate. 2013;73(14):1495-506.
10. Pedersen MØ, Larsen A, Stoltenberg M, Penkowa M. The role of metallothionein in oncogenesis and cancer prognosis. Prog Histochem Cytochem. 2009;44:29-64.

11. Kling P, Modig C, Mujahed H, Khalaf H, von Hofsten J, Olsson PE. Differential regulation of the rainbow trout (Oncorhynchus mykiss) MT-A gene by nuclear factor interleukin-6 and activator protein-1. BMC Mol Biol. 2013;14:28. doi:10.1186/1471-2199-14-28.

12. Chen L, Ma L, Bai Q, Zhu X, Zhang J, Wei Q, et al. Heavy metalinduced metallothionein expression is regulated by specific protein phosphatase 2A complexes. J Biol Chem. 2014;289:22413-26.

13. Zhao WJ, Song Q, Wang YH, Li KJ, Mao L, Hu X, et al. Znresponsive proteome profiling and time-dependent expression of proteins regulated by MTF-1 in A549 cells. PLoS One. 2014;9(8):e105797. doi:10.1371/journal.pone.0105797.

14. Gumulec J, Balvan J, Sztalmachova M, Raudenska M, Dvorakova V, Knopfova L, et al. Cisplatin-resistant prostate cancer model: differences in antioxidant system, apoptosis and cell cycle. Int $\mathrm{J}$ Oncol. 2014;44(3):923-33.

15. Fu J, Lv H, Guan H, Ma X, Ji M, He N, et al. Metallothionein $1 \mathrm{G}$ functions as a tumor suppressor in thyroid cancer through modulating the PI3K/Akt signaling pathway. BMC Cancer. 2013;13:462. doi:10.1186/1471-2407-13-462.

16. Habel N, Hamidouche Z, Girault I, Patiño-García A, Lecanda F, Marie PJ, et al. Zinc chelation: a metallothionein 2A's mechanism of action involved in osteosarcoma cell death and chemotherapy resistance. Cell Death Dis. 2013;4:e874. doi:10.1038/cddis.2013. 405.

17. Pan Y, Huang J, Xing R, Yin X, Cui J, Li W, et al. Metallothionein $2 \mathrm{~A}$ inhibits NF-kB pathway activation and predicts clinical outcome segregated with TNM stage in gastric cancer patients following radical resection. J Transl Med. 2013;11:173. doi:10.1186/ 1479-5876-11-173.

18. Starska K, Krześlak A, Forma E, Olszewski J, Lewy-Trenda I, Osuch-Wójcikiewicz E, et al. Genetic polymorphism of metallothionein 2A and risk of laryngeal cancer in a Polish population. Med Oncol. 2014;31:75. doi:10.1007/s12032-014-0075-8.

19. Starska K, Kreślak A, Forma E, Olszewski J, Morawiec-Sztandera $\mathrm{A}$, Aleksandrowicz $\mathrm{P}$, et al. The $-5 \mathrm{~A} / \mathrm{G}$ single-nucleotide polymorphism in the core promoter region of MT2A and its effect on allelespecific gene expression and $\mathrm{Cd}, \mathrm{Zn}$ and $\mathrm{Cu}$ levels in laryngeal cancer. Toxicol Appl Pharmacol. 2014;280:256-63.

20. Krześlak A, Forma E, Jóźwiak P, Szymczyk A, Smolarz B, Romanowicz-Makowska H, et al. Metallothionein 2A genetic polymorphisms and risk of ductal breast cancer. Clin Exp Med. 2014;14(1):107-13.

21. Krześlak A, Forma E, Chwatko G, Jóźwiak P, Szymczyk A, Wilkosz J, et al. Effect of metallothionein 2A gene polymorphism on allele-specific gene expression and metal content in prostate cancer. Toxicol Appl Pharmacol. 2013;268:278-85.

22. Forma E, Krześlak A, Wilkosz J, Jozwiak P, Szymczyk A, Rozanski $\mathrm{W}$, et al. Metallothionein 2A genetic polymorphisms and risk of prostate cancer in a Polish population. Cancer Genet. 2012;205: 432-5.

23. Kita K, Miura M, Yoshida M, Yamazaki K, Ohkubo T, Imai Y, et al. Potential effect on cellular response to cadmium of a singlenucleotide $\mathrm{A}>\mathrm{G}$ polymorphism in the promoter of the human gene for metallothionein IIA. Hum Genet. 2006;120:553-60.

24. Brazão-Silva MT, Cardoso SV, de Faria PR, Dias FL, Lima RA, Eisenberg AL, et al. Adenoid cystic carcinoma of the salivary gland: a clinicopathological study of 49 cases and of metallothionein expression with regard to tumour behaviour. Histopathology. 2013;63(6):802-9.

25. Gumulec J, Raudenska M, Adam V, Kizek R, Masarik M. Metallothionein - immunohistochemical cancer biomarker: a meta-analysis. PLoS One. 2014;9(1):e85346. doi:10.1371/journal. pone.0085346. 
26. Theocharis S, Klijanienko J, Giaginis C, Rodriguez J, Jouffroy T, Girod A, et al. Metallothionein expression in mobile tongue squamous cell carcinoma: associations with clinicopathological parameters and patient survival. Histopathology. 2011;59:514-25.

27. Pastuszewski W, Dziegiel P, Krecicki T, Podhorska-Okolow M, Ciesielska U, Gorzynska E, et al. Prognostic significance of metallothionein, p53 protein and $\mathrm{Ki}-67$ antigen expression in laryngeal cancer. Anticancer Res. 2007;27:335-42.

28. Krouse JH. Development of a staging system for inverted papilloma. Laryngoscope. 2000;110:965-8.

29. Barnes L, Eveson JW, Reichart P, Sidransky D. World Health Organization classification of tumors. pathology and genetics of head and neck tumours. Lyon: IARC; 2005.

30. Thirumoorthy N, Shyam Sunder A, Manisenthil Kumar K, Senthil Kumar M, Ganesh G, Chatterjee M. A review of metallothionein isoforms and their role in pathophysiology. World J Surg Oncol. 2011;9:54. doi:10.1186/1477-7819-9-54.

31. Kanda M, Nomoto S, Okamura Y, Nishikawa Y, Sugimoto H, Kanazumi N, et al. Detection of metallothionein $1 \mathrm{G}$ as a methylated tumor suppressor gene in human hepatocellular carcinoma using a novel method of double combination array analysis. Int $\mathrm{J}$ Oncol. 2009;35(3):477-83.

32. Seibold P, Hall P, Schoof N, Nevanlinna H, Heikkinen T, Benner A, et al. Polymorphisms in oxidative stress-related genes and mortality in breast cancer patients-potential differential effects by radiotherapy? Breast. 2013;22(5):817-23.

33. Seibold P, Hein R, Schmezer P, Hall P, Liu J, Dahmen N, et al. Polymorphisms in oxidative stress-related genes and postmenopausal breast cancer risk. Int J Cancer. 2011;129:1467-76.

34. Kayaaltı Z, Aliyev V, Söylemezoğlu T. The potential effect of metallothionein $2 \mathrm{~A}-5 \mathrm{~A} / \mathrm{G}$ single nucleotide polymorphism on blood cadmium, lead, zinc and copper levels. Toxicol Appl Pharmacol. 2011;256:1-7.

35. Kayaalti Z, Mergen G, Söylemezoğlu T. Effect of metallothionein core promoter region polymorphism on cadmium, zinc and copper levels in autopsy kidney tissues from a Turkish population. Toxicol Appl Pharmacol. 2010;245:252-5.

36. Kayaaltı Z, Sahiner L, Durakoğlugil ME, Söylemezoğlu T. Distributions of interleukin-6 (IL-6) promoter and metallothionein 2A (MT2A) core promoter region gene polymorphisms and their associations with aging in Turkish population. Arch Gerontol Geriatr. 2011;53(3):354-8.

37. Kayaalti Z, Söylemezoğlu T. The polymorphism of core promoter region on metallothionein 2A-metal binding protein in Turkish population. Mol Biol Rep. 2010;37(1):185-90.
38. McElroy JA, Bryda EC, McKay SD, Schnabel RD, Taylor JF. Genetic variation at a metallothionein $2 \mathrm{~A}$ promoter singlenucleotide polymorphism in white and black females in Midwestern United States. J Toxicol Environ Health. 2010;73: 1283-7.

39. Starska K, Bryś M, Forma E, Olszewski J, Pietkiewicz P, LewyTrenda I, et al. The effect of metallothionein $2 \mathrm{~A}$ core promoter region single-nucleotide polymorphism on accumulation of toxic metals in sinonasal inverted papilloma tissues. Toxicol Appl Pharmacol. 2015. doi:10.1016/j.taap.2015.04. 008.

40. Ahamed M, Alhadlaq HA. Nickel nanoparticle-induced dose-dependent cyto-genotoxicity in human breast carcinoma MCF-7 cells. Onco Targets Ther. 2014;7:269-80.

41. Tokar EJ, Benbrahim-Tallaa L, Waalkes MP. Metal ions in human cancer 620 development. Met Ions Life Sci. 2011;8:375-401.

42. Wong VC, Morse JL, Zhitkovich A. p53 activation by Ni(II) is a HIF- $1 \alpha$ independent response causing caspases 9/3-mediated apoptosis in human lung cells. Toxicol Appl Pharmacol. 2013;269: 233-9.

43. Tekin D, Kayaaltı Z, Söylemezoğlu T. The effects of metallothionein $2 \mathrm{~A}$ polymorphism on lead metabolism: are pregnant women with a heterozygote genotype for metallothionein $2 \mathrm{~A}$ polymorphism and their newborns at risk of having higher blood lead levels? Int Arch Occup Environ Health. 2012;85(6):631-7.

44. Gansukh T, Donizy P, Halon A, Lage H, Surowiak P. In vitro analysis of the relationships between metallothionein expression and cisplatin sensitivity of non-small cellular lung cancer cells. Anticancer Res. 2013;33:5255-60.

45. Dutsch-Wicherek M, Popiela TJ, Klimek M, Rudnicka-Sosin L, Wicherek L, Oudinet JP, et al. Metallothionein stroma reaction in tumor adjacent healthy tissue in head and neck squamous cell carcinoma and breast adenocarcinoma. Neuro Endocrinol Lett. 2005;26:567-74.

46. Kobierzycki C, Pula B, Skiba M, Jablonska K, Latkowski K, Zabel $\mathrm{M}$, et al. Comparison of minichromosome maintenance proteins (MCM-3, MCM-7) and metallothioneins (MT-I/II, MT-III) expression in relation to clinicopathological data in ovarian cancer. Anticancer Res. 2013;33(12):5375-83.

47. Liang GY, Lu SX, Xu G, Liu XD, Li J, Zhang DS. Expression of metallothionein and Nrf2 pathway genes in lung cancer and cancersurrounding tissues. World J Surg Oncol. 2013;11:199. doi:10. 1186/1477-7819-11-199.

48. Werynska B, Pula B, Muszczynska-Bernhard B, Gomulkiewicz A, Piotrowska A, Prus R, et al. Metallothionein $1 \mathrm{~F}$ and 2A overexpression predicts poor outcome of non-small cell lung cancer patients. Exp Mol Pathol. 2013;94(1):301-8. 